\title{
Serum reg protein level is not related to the beta cell destruction/regeneration process during early phases of diabetogenesis in type I diabetes
}

\author{
Marie-Agnès Christofilis ${ }^{1}$, Jacqueline Carrere ${ }^{2}$, Catherine Atlan-Gepner ${ }^{1}$, Catherine Zevaco-Mattei ${ }^{1}$, \\ Charles Thivolet ${ }^{3}$, Nathalie Baeza ${ }^{2}$, Catherine Figarella ${ }^{2}$ and Bernard Vialettes ${ }^{1}$ \\ ${ }^{1}$ Service de Nutrition, Maladies Métaboliques et Endocrinologie, UPRES EA 2193, Hôpital Sainte Marguerite, Boulevard Sainte Marguerite, \\ F13009 Marseille, France, ${ }^{2}$ Groupe de Recherche sur les Glandes Exocrines, Faculté de Médecine, Boulevard Jean Moulin, F13385 Marseille, France \\ and ${ }^{3}$ INSERM U197, Lyon, France \\ (Correspondence should be addressed to B Vialettes; Email: bvialettes@mail.ap.hm.fr)
}

\begin{abstract}
Objective: In type I diabetes mellitus, early markers of beta cell damage are needed in order to detect the infraclinical development of the disease. The reg protein may be a good candidate, as the reg gene has been proposed to play a role in the pancreatic beta cell destruction/regeneration process during diabetogenesis in animal models of autoimmune diabetes. The aim of this study was to test the hypothesis whether serum reg protein level could be representative of either the destructive or regenerative process at the beta cell level during the early phases of type I diabetes in humans.

Design and methods: We used a highly specific immunoassay to measure serum reg protein level in controls and in three groups of either diabetes prone or diabetic subjects: recently diagnosed diabetic patients, long-standing diabetic patients and islet cell antibody-positive non-diabetic subjects.

Results: We found no significant difference between the values observed in these three groups in comparison with control group $(90.7 \pm 18.1 \mathrm{ng} / \mathrm{ml}, 83.1 \pm 5.6 \mathrm{ng} / \mathrm{ml}, 98.7 \pm 24.5 \mathrm{ng} / \mathrm{ml}$ vs $85.5 \pm$ $5.6 \mathrm{ng} / \mathrm{ml}$ respectively). Moreover, when the insulin reserve was evaluated at 6 months in the recently diagnosed group, serum reg protein levels were not different between patients with or without residual insulin secretion (at onset: $103 \pm 42 \mathrm{vs} 70.3 \pm 8.5 \mathrm{ng} / \mathrm{ml}$ respectively; at 6 months: $79.7 \pm 25.8 \mathrm{ng} / \mathrm{ml}$ vs $81.6 \pm 15 \mathrm{ng} / \mathrm{ml}$ respectively). In contrast, trypsin levels were significantly lower in every group of diabetic patients. Results were expressed as means \pm s.E.M. and groups compared by Student's $t$-test $(P<0.05)$.

Conclusions: We conclude that serum reg protein level cannot be used as a marker for the progression of the diabetogenic process in type I diabetes.
\end{abstract}

European Journal of Endocrinology 141 368-373

\section{Introduction}

Type I diabetes mellitus is an autoimmune disease characterized by the selective destruction of the insulinsecreting pancreatic beta cells. The clinical onset is preceded by a silent period of variable duration (pre-type I diabetes) during which the autoimmune reaction progresses. Screening for pre-type I is a challenge that would allow an early therapeutic intervention, before the overt diabetes. Such diagnosis is at the present time based on a combination of immunological (islet-cell autoantibodies as ICA, GAD-A and IA2-A and antiinsulin antibodies) and metabolic (acute insulin response during i.v. glucose tolerance test) markers (1-3). However, these markers lack specificity. Indeed, chronic anti beta cell autoimmunity has been described without development of diabetes $(1,4)$. Moreover, alteration of the first phase insulin response to glucose represents a late marker of beta cell damage (5-7). A successful therapeutic intervention, occurring as soon as possible in the natural history of type I diabetes, should require the use of marker(s) reflecting the progression of the diabetogenic process. Indeed, measurement of reg protein might be a good candidate for this purpose. The reg protein is normally secreted by exocrine pancreatic cells and reg gene overexpression has previously been shown to be associated with regeneration of pancreatic islets (8-11). In animal models of autoimmune diabetes, pancreatic overexpression of reg mRNA has been reported (12-14) during active phases of diabetogenesis and reg gene proposed to play a role in the destruction/regeneration process during autoimmune aggression of beta cells (reviewed in ref. 15). In humans, as in rodents, there are a number of arguments which indicate that regenerative phenomena may occur during diabetogenesis. Gepts (16) has 
observed some beta cell enriched islets in the pancreas of diabetic patients who died a few months after clinical onset of the disease, suggesting that some regenerative processes occur during this phase of the disease. Transient glucose intolerances associated with autoimmune markers have been noted in twin studies, confirming that, on rare occasions, beta cells could overcome autoimmune aggression (4). Regeneration of endocrine cells from the duct, mainly with the glucagon cell phenotype, has been also noted by O'Reilly (17) in the non-obese diabetic (NOD) mouse. As exocrine pancreatic proteins can be measured in blood, we made the assumption that serum reg protein levels might reflect pancreatic expression during the early phases of the disease in diabetic patients, and then these could be a marker of the destruction/regeneration balance. Accordingly, the reg protein level was measured in either recently diagnosed diabetic patients or first relatives who were at risk of diabetes, due to exhibiting positive high titer islet cell antibodies. These levels were compared with both a control population and a group of longstanding diabetic patients. In addition, reg protein levels were correlated to the presence or absence of detectable $C$-peptide secretion during the first year of the disease in order that it might reflect the possible regenerative process during the honeymoon period of the disease.

\section{Material and methods}

\section{Subjects}

Seventy-two subjects were retrospectively studied:

(1) Twenty-two adult controls (blood donors from the Centre Régional de Transfusion Sanguine, Marseille, aged 20-50 years) without any diabetic relative and not suffering from diabetes, pancreatic or digestive diseases. (2) Twenty-one recently diagnosed diabetic patients (14 males and 7 females aged 24-46 years). The patients were treated at onset by intensive insulin treatment with continuous insulin infusion during 5-7 days, then followed by conventional insulin therapy with 2-3 daily subcutaneous injections. Blood samples had been taken at onset and at 6 and 12 months following diagnosis. In parallel, beta-cell reserve was evaluated by measuring plasma C-peptide before and after i.v. injection of $1 \mathrm{mg}$ glucagon (Glucagen, Novo-Nordisk, BoulogneBillancourt, France) using a commercially available kit. This test was performed only if fasting plasma glucose was in the $4.4-11 \mathrm{mmol} / \mathrm{l}$ range.

(3) Twenty long-standing diabetic patients (15 males and 5 females aged 4-46 years, duration of diabetes 235 years) with no residual insulin secretion (e.g. undetectable plasma $\mathrm{C}$-peptide at fasting).

(4) Nine non-diabetic subjects (five males and four females, aged 6-40 years, first degree relatives of type I diabetic patients) with high titers of islet cell antibodies (ICA) (>40 JDF units). This group was considered as being at high risk of type I diabetes. Indeed, seven out of these nine subjects later became diabetic (assays were performed on blood samples taken 1-5 years before clinical onset). One is still not diabetic. One was lost.

\section{Immunoassays}

Preparation of serum samples Blood samples collected in standard tubes were taken in the morning after an overnight fast, allowed to clot at room temperature, and centrifuged for $10 \mathrm{~min}$ at $1700 \mathrm{~g}$. The sera were then stored frozen at $-20^{\circ} \mathrm{C}$ until assay.

Immunoenzymatic assay of the reg protein Serum reg protein levels were measured by direct sandwich immunoassay as previously described (18) on $0.1 \mathrm{ml}$ serum diluted to a final volume of $0.3 \mathrm{ml}$ in the diluting medium (0.2 mol/l phosphate buffer, $\mathrm{pH} 7.2,10 \%$ rabbit serum). As a solid phase, $6.5 \mathrm{~mm}$ diameter polystyrene balls were coated with specific IgG, and horseradish peroxidase labeled IgG was used as a secondary antibody. Peroxidase activity was measured using $o$-phenylenediamine dihydroxychloride as substrate. The sensitivity of the assay was $0.3 \mathrm{ng} / \mathrm{ml}$ and the within-run and day-to-day coefficients of variation around 10\% consistent with most ELISA procedures. As previously published (19), it was checked that antibodies prepared against reg protein isolated from pancreatic juice did not react with another member of the reg superfamily such as PAP/HIP protein.

Determination of serum trypsinogen concentration Blood trypsino(gene) levels were measured by an immunoenzymatic assay as previously described (20). The assay was shown to specifically recognize the major human trypsinogen:trypsinogen 1 or 'cationic' trypsinogen.

\section{ICAs}

ICAs were measured by indirect immunofluorescence on cryostat sections of human pancreas (blood group $\mathrm{O}$ ) in accordance with Juvenile Diabetes Foundation (JDF) standardization workshops (threshold limit in our laboratory > 5 JDF units).

\section{Statistical analysis}

Results were expressed in mean \pm s.E.M. They were compared using a two-tailed Student $t$-test and the significance threshold was $P<0.05$.

\section{Results}

\section{Serum reg values in recently diagnosed and in pre-type I diabetes are not different to that found in controls and long-standing diabetes}

In recently diagnosed patients, mean serum reg protein levels were $90.7 \pm 18.1 \mathrm{ng} / \mathrm{ml}$ at onset, and $77.5 \pm 8.4 \mathrm{ng} / \mathrm{ml}$ and $67.5 \pm 4.0 \mathrm{ng} / \mathrm{ml}$ at 6 and 12 months following diagnosis, respectively. Although 
mean serum reg protein levels tended to decrease, no significant difference was observed during the 1-year follow-up. These values were not significantly different from the control values $(85.5 \pm 5.6 \mathrm{ng} / \mathrm{ml})$. Two isolated high values (440 and $220 \mathrm{ng} / \mathrm{ml}$ ) were noted in two different patients at onset and 6 months following diagnosis respectively, without evidence of clinical or biological particularities in these patients.

In long-standing diabetic patients, mean serum reg protein level was $83.1 \pm 4.8 \mathrm{ng} / \mathrm{ml}$. Two values higher than $1000 \mathrm{ng} / \mathrm{ml}$ were not taken into account because they concerned patients with terminal chronic renal failure. No correlation was observed between serum reg protein level and duration of diabetes.

In ICA-positive subjects, serum reg protein levels were $98.6 \pm 24.5 \mathrm{ng} / \mathrm{ml}$. These values were not significantly different from control values. We observed an isolated high value of $292 \mathrm{ng} / \mathrm{ml}$ in a patient whose evolution to diabetes is not known. One patient out of the nine studied is still not diabetic: serum reg protein level in this patient did not differ from that in the others $(80 \mathrm{ng} / \mathrm{ml})$. Distribution of individual serum reg protein levels in recently diagnosed diabetic patients, long-standing diabetic patients and ICA positive subjects is shown in Fig. 1.

\section{Lack of relationship between serum reg protein levels and residual beta cell function during the first year of the disease}

We compared two subgroups of the recently diagnosed diabetic population which differed only in the quality of the residual insulin reserve during the 12 months following clinical onset. After 6 months, 9 out of 19 patients presented a marked residual insulin secretion (defined as a plasma C-peptide level higher than $0.5 \mathrm{nmol} / \mathrm{l}, 5 \mathrm{~min}$ after an intravenous infusion of glucagon). Serum reg protein levels in these nine patients did not differ from the remaining ten who were considered to have no or low insulin reserve $(103 \pm 42 \mathrm{ng} / \mathrm{ml}$ and $79.7 \pm 25.8 \mathrm{ng} / \mathrm{ml}$ vs $70.3 \pm$ $8.5 \mathrm{ng} / \mathrm{ml}$ and $81.6 \pm 15 \mathrm{ng} / \mathrm{ml}$ at onset and 6 months following diagnosis, respectively) (Fig. 2). No correlation was observed between serum reg protein values and post-glucagon $C$-peptide levels at any time during the first year follow-up of the disease.

\section{Serum trypsin levels were decreased in diabetic patients}

The fasting serum values of trypsin in recently diagnosed and long-lasting diabetic patients were significantly decreased in comparison with controls $(14.8 \pm 1.24 \mathrm{ng} / \mathrm{ml}$ and $11.3 \pm 1.3 \mathrm{ng} / \mathrm{ml}$ vs $23.28 \pm$ $1.58 \mathrm{ng} / \mathrm{ml}$ respectively, $P<0.001)$. In contrast, serum trypsin levels of ICA-positive first degree relatives were not statistically different from the controls (16.7 \pm $2.63 \mathrm{ng} / \mathrm{ml}$ ). In the diabetic subjects there was a tendency to a progressive decrease of trypsin levels with the duration of the disease, but the differences reached the significant threshold only when one-tailed test was used; at diagnosis: $14.8 \pm 5.69 \mathrm{ng} / \mathrm{ml}, 6$ months later:

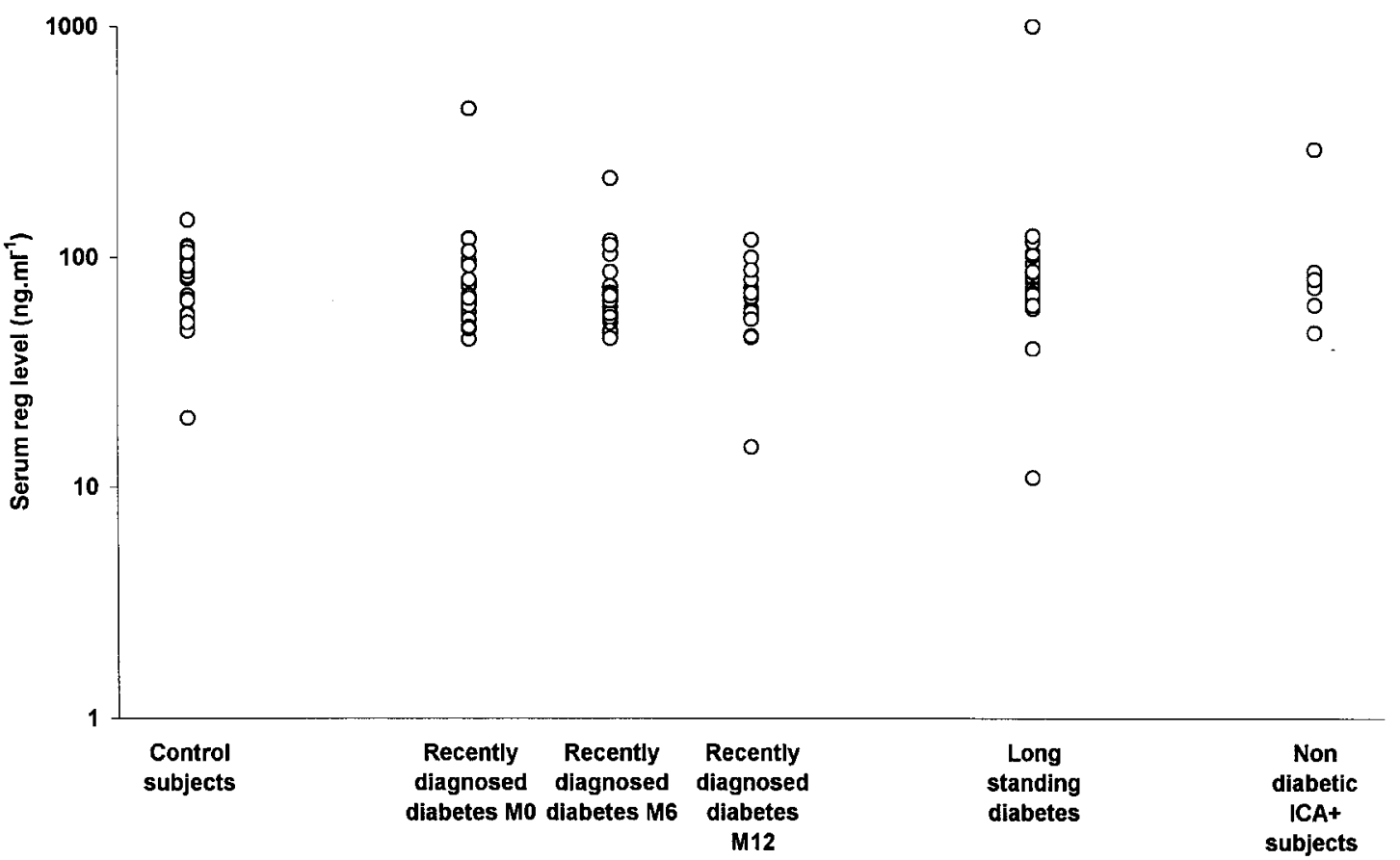

Figure 1 Distribution of serum reg protein levels in controls, patients with either recently diagnosed (M0: clinical onset, M6 and M12: 6 and 12 months later, respectively) or long-standing type I diabetes and subjects considered to be at risk of diabetes (ICA positivity, seven became diabetic later), represented on a semi-logarithmic scale. 


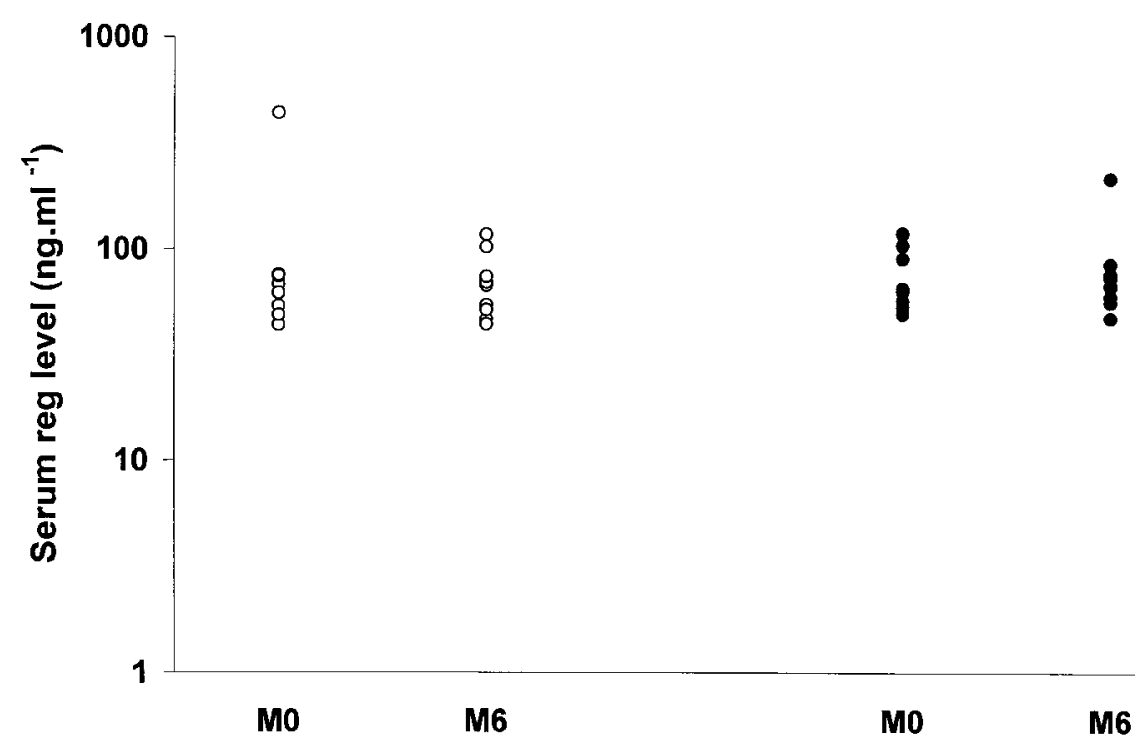

Figure 2 Serum reg protein levels in recently diagnosed type I diabetic patients at 6 (M6) and 12 (M12) months as a function of the presence of residual insulin secretion $(\bullet$, patients with a post-glucagon $\mathrm{C}$-peptide value higher than $0.5 \mathrm{nmol} / \mathrm{l} ; \mathrm{O}$, values below this limit at 6 months).

$14.3 \pm 1.13 \mathrm{ng} / \mathrm{ml}, 12$ months later: $13 \pm 1.11 \mathrm{ng} / \mathrm{ml}$, long-standing diabetics: $11 \pm 1.3 \mathrm{ng} / \mathrm{ml}$. No correlation was found between reg protein and trypsin levels in any group or the whole population.

\section{Discussion}

This pilot study shows that the measurement of serum reg protein levels with a highly sensitive and specific method failed to detect the destruction/regeneration phenomenon in the pancreas of type I diabetic patients. Indeed, in both ICA-positive pre-diabetic subjects and recently diagnosed diabetic patients, serum reg protein levels were not different to that found in the control group. In addition, during the year following diagnosis of clinical diabetes, the course of serum reg protein levels was similar in two groups differing only in the quality of the residual insulin reserve. Therefore, in our study, plasma reg protein level was influenced neither by the diabetogenic risk before the disease, nor by the residual beta cell mass during the honeymoon period. The high variability of serum reg protein levels between individuals is also worth noting, and has previously been reported by others $(21,22)$. Nevertheless, pancreatic overexpression of reg gene has been observed in murine autoimmune diabetes such as BB rats and NOD mice. In these diabetic prone strains, expression of reg gene was specially increased during the active phase of diabetogenesis, e.g. 90-day-old diabetes prone BB rats (12) or NOD female mice and cyclophosphamideinjected NOD male mice $(13,14)$.

Unfortunately, the serum reg protein level does not seem to reliably reflect the pancreatic production, at least not in human type I diabetes. This discrepancy between secretion and plasma level has already been observed for some other proteins produced by exocrine pancreatic cells. For instance, lactoferrin, which is secreted in excess into pancreatic juice during chronic calcifying pancreatitis, has been found at a normal level in blood of patients suffering from this disease (23). In contrast to reg protein, some changes of serum trypsin values have been observed in diabetic patients. There was a decrease of this parameter, which had the tendency to be more pronounced with a longer duration of the disease. These results are in agreement with previously published data $(24,25)$. The lower trypsin levels in plasma of insulin-dependent diabetic patients have been attributed to a decrease of exocrine pancreatic secretion in this disease $(26,27)$. Even if a ratio reg protein/trypsin was considered in this study, the highest values were observed mainly in long-standing diabetes, and not in the more active periods of diabetogenesis. The lack of absolute or relative increase of reg protein in serum during early phases of type I diabetes can be explained by several reasons. Indeed, in animal models of islet regeneration, reg seems to act mainly as an autocrine/paracrine factor. Islet regeneration could not be transferred by parabiotic experiments in a model of cellophane-wrapping of the pancreas in the hamster (28). In another model (ligation of pancreatic duct), it was shown that no regeneration occurs downstream the ligation (29). Very similar results were reported in a third model of islet neogenesis by selective alloxan infusion in mice (30). Moreover, it is noteworthy that serum reg immunoreactive material can have extrapancreatic sources including small bowels, gastric 
mucosa or kidney as reg gene expression has been identified in all three tissues (31). We had the opportunity to study a patient with a subtotal pancreatectomy (results not shown). The serum reg protein level was within the normal range, despite undetectable serum immunoreactive trypsin. This result is in agreement with findings from our group and others of an absence of correlation between reg protein and immunoreactive trypsin serum levels in 160 subjects including controls and patients with cystic fibrosis or chronic pancreatitis $(19,22)$. We had the opportunity to measure reg protein levels in serum of controls during nutritional and pharmacological explorations; $36-\mathrm{h}$ fasting $(61 \pm 19$ to $64 \pm 11 \mathrm{ng} / \mathrm{ml}, n=2)$, oral glucose load (fasting: $80 \pm 17,60 \mathrm{~min}$ post load: $82 \pm 18,120 \mathrm{~min}$ post load: $76 \pm 10 \mathrm{ng} / \mathrm{ml}, n=3$ ), fat-enriched test meal $(77 \pm 10$ to $77 \pm 11 \mathrm{ng} / \mathrm{ml}$, $n=2)$ and insulin-induced hypoglycemia (68 \pm 19 to $70 \pm 26 \mathrm{ng} / \mathrm{ml}, n=2$ ) (unpublished results). Any of these tests was able to induce a significant rise of serum reg protein values. Another possible explanation for the discrepancies between human and animal data could be the fact that reg gene overexpression could be a very transient phenomenon. In various animal models of islet regeneration, reg gene overexpression occurs very early in pancreas (1-2 days) and lasts only a few days (less than 1 week) (8-11). In our series, it is noteworthy that three patients in both prediabetic and diabetic groups exhibited transient high serum reg levels. None of these patients suffered from acute or chronic pancreatitis, cancer of the digestive tract or chronic renal failure, pathologies in which elevated reg serum levels have been previously reported $(21,22)$. Transient high production from the pancreatic site cannot be excluded in these subjects.

In conclusion, these results are somewhat disappointing, as a reliable serum marker of beta cell damage is needed in order to improve the diagnostic value of the usual immune markers of pretype I diabetes (autoantibodies as ICA, GAD-A, IA2-A and insulin autoantibodies) and precisely predict the speed of the beta cell destruction. The beta cell function abnormalities such as the low acute insulin response to i.v. glucose seem to be too late a marker, occurring just 1-2 years before clinical onset. Despite the absence of predictive value of serum reg protein level in the at-risk patients, we can hope that improvement of the knowledge of endocrine/exocrine interactions in the pancreas submitted to autoimmune aggression will clarify the role of this protein during diabetogenesis in the future.

\section{Acknowledgements}

We are indebted to the Centre Régional de Transfusion Sanguine for the gift of control sera. This work has been supported by grants from the French Ministry of Health and Solidarity (PHRC), Novo-Nordisk France (French Society of Endocrinology) and AFD-ALFEDIAM.

\section{References}

1 Verge C, Gianani R, Yu L, Pietropaolo M, Smith T, Jackson R et al. Late progression to diabetes and evidence for chronic $\beta$ cell autoimmunity in identical twins of patients with type I diabetes. Diabetes 199544 11796-1179.

2 Pastore MR, Bazzigaluppi E, Bonfanti R, Dozio N, Sergi A, Balini A et al. Two-step islet auto antibody screening for risk assessment of type 1 diabetes. Diabetes Care 199821 1446-1450.

3 Kulmala P, Savola K, Patersen JS, Vahasalo P, Karjalainen J, Lopponen T et al. Prediction of insulin dependent diabetes mellitus in siblings of children with diabetes. A population based study. Journal of Clinical Investigation $1998101327-336$.

4 Leslie R \& Pyke D. Concordance between twins for $\beta$ cell autoimmunity. Diabetes 1996451284 (letter).

5 Bleich D, Jackson RA, Soeldner JS \& Eisenbarth GS. Analysis of metabolic progression to type 1 diabetes in ICA+ relatives of patients with type 1 diabetes. Diabetes Care 199013 111-118.

6 Vialettes B, Zevaco-Mattei C, Thirion X, Lassmann-Vague V, Pieron $\mathrm{H}$, Mercier $\mathrm{P}$ et al. Acute insulin response to glucose and glucagon in subjects at risk of developing type 1 diabetes. Diabetes Care 199013 111-118.

7 Vardi P, Crisa L \& Jackson RA. Predictive value of intravenous glucose tolerance test insulin secretion less than or greater than the first percentile in islet cell antibody positive relatives of type 1 (insulin-dependent) diabetic patients. Diabetologia 199134 93102.

8 Terazono K, Yamamoto H, Takasawa S, Shiga K, Yonemura Y, Tochino $\mathrm{Y}$ et al. A novel gene activated in regenerating islets. Journal of Biological Chemistry 1988263 2111-2114.

9 Miyaura C, Chen L, Appel M, Alam T, Inman L, Hughes S et al. Expression of reg/PSP, a pancreatic exocrine gene: relationship to changes in islet $\beta$-cell mass. Molecular Endocrinology $19915226-$ 234.

10 Rafaeloff R, Barlow SW, Rosenberg L \& Vinik AI. Expression of reg gene in the Syrian golden hamster pancreatic islet regeneration model. Diabetologia 199538 906-913.

11 Zenilman M, Perfetti R, Swinson K, Magnuson T \& Shuldiner A. Pancreatic regeneration (reg) gene expression in a rat model of islet hyperplasia. Surgery $1996119576-584$.

12 Baeza N, Moriscot C. Figarella C, Guy-Crotte O \& Vialettes B. Reg protein: a potential beta-cell-specific growth factor? Diabetes and Metabolism 199622 229-234.

13 Baeza N, Sanchez D, Vialettes B \& Figarella C. Specific reg II gene over expression in the non obese diabetic mouse pancreas during active diabetogenesis. FEBS Letter 1997416 364-368.

14 Bone A, Banister S \& Zhang S. Islet cell defence and repair mechanisms in insulin-dependent diabetes: a role for the pancreatic regenerating (reg) gene? Biochemical Society Transactions $19942237-41$.

15 Baeza NJ, Moriscot CI, Renaud WP, Okamoto H, Figarella CG \& Vialettes BH. Pancreatic regenerating gene overexpression in the non obese diabetic mouse during active diabetogenesis. Diabetes $19964567-70$.

16 Gepts W. Pathology of IDDM in man. Diabetes, pp 99-106. Amsterdam: Excerpta Medica, 1983.

17 O'Reilly LA, Gu D, Sarvetnick N, Edlund H, Phillips JM, Fulford T et al. $\alpha$-Cell neogenesis in an animal model of IDDM. Diabetes $199746599-606$.

18 Carrere J, Guy-Crotte O \& Figarella C. Human pancreatic reg protein. immunoenzymatic assay and molecular form in serum. Clinica et Chimica Acta 1998273 185-194.

19 Carrère J, Guy-Crotte O, Gaia E \& Figarella C. Immunoreactive pancreatic reg protein in sera from cystic fibrosis with and without pancreatic insufficiency. Gut 199944 545-551.

20 Carrere J, Grataroli R, Marfin J, Ferrua B, Thouvenot JP \& Figarella C. Non competitive enzyme immuno assay of human trypsin 1. Journal of Immunological Methods 198360 235-242.

21 Schmiegel W, Burchert M, Kalthoff H, Roeder C, Bützow G, Grimm $\mathrm{H}$ et al. Immunochemical characterization and quantitative distribution of pancreatic stone protein in sera and pancreatic 
secretion in pancreatic disorders. Gastroenterology 199099 $1421-1430$.

22 Hayakawa T, Kondo T, Shibata T, Kitagawa M, Sakai Y, Sobajima $\mathrm{H}$ et al. Serum pancreatic stone protein in pancreatic disease. International Journal of Gastroenterology 1993 13 97-103.

23 Figarella C, Gaia E \& Piantino P. Plasma lactoferrin levels in patients with chronic calcifying pancreatitis. Digestion 198327 185-187.

24 Landin-Olsson M, Borgstrom A, Blom L, Sundkvist G \& Lernmark A. Immunoreactive trypsin (ogen) in the sera of children with recent onset insulin-dependent diabetes and matched controls. The Swedish Childhood Diabetes Group. Pancreas 19905 241247.

25 Lorini R, Cortona L, Scotta MS, Melzi d'Eril GV \& Severi F. Exocrine pancreatic function in children and adolescents with insulindependent diabetes mellitus. Diabetes Research and Clinical Practice $19908263-267$.

26 Domschke W, Tympner F, Domschke S \& Demling L. Exocrine pancreatic function in juvenile diabetes. American Journal of Digestive Disorders 197520 309-312.

27 Frier BM, Saunders JH, Wormsley KG \& Bouchier IA. Exocrine pancreatic function in juvenile-onset diabetes mellitus. Gut 1976 $9685-691$.
28 Rosenberg L, Kahlenberg M, Vinik A \& Duguid W. Paracrine/ autocrine regulation of pancreatic islet cell proliferation and differentiation in the hamster: studies using parabiosis. Clinical and Investigative Medicine 199619 3-12.

29 Wang R, Klöppel G \& Bouwens L. Duct-to islet-cell differentiation and islet growth in the pancreas of duct-ligated adult rats. Diabetologia 199538 1405-1411.

30 Waguri M, Yamamoto K, Miyagawa J. Tochino Y, Yamamori K. Kajimoto Yet al. Demonstration of two different processes of $\beta$ cell regeneration in a new diabetic mouse model induced by selective perfusion of alloxan. Diabetes 199746 1281-1290.

31 Watanabe T, Yonekura H, Terazono K, Yamamoto H \& Okamoto $\mathrm{H}$. Complete nucleotide sequence of human reg gene and its expression in normal and tumoral tissues. The reg protein, pancreatic stone protein, and pancreatic thread protein are one and the same product of the gene. Journal of Biological Chemistry $19902657432-7439$.

Received 19 March 1999

Accepted 2 July 1999 